\title{
Anti-hepatitis B surface (anti-HBs) seroprotection in children with acute lymphoblastic leukemia post hepatitis B vaccination in Indonesia
}

\author{
Yustinah $^{1 *}$, Nenny Sri Mulyani², Roni Naning² \\ ${ }^{1}$ Fatima District Hospital, Ketapang District, West Kalimantan, ${ }^{2}$ Department of Pediatrics, \\ Faculty of Medicine Universitas Gadjah Mada/Dr. Sardjito General Hospital Yogyakarta
}

\begin{abstract}
Children with acute lymphoblastic leukemia (ALL) receiving chemotherapy are at high risk for developing hepatitis B infection. Protective effect of hepatitis B vaccination in children with ALL in Indonesia has not been investigated yet. The aim of study was to determine the proportion difference of anti-HBs seroprotection between children with ALL and without malignancy post hepatitis B vaccination. We had conducted a case-control study from January to February 2012 at Dr. Sardjito General Hospital, Yogyakarta. We ascertained 1-15 years old children with ALL receiving chemotherapy and without malignancy who had hepatitis $B$ vaccination. Sixty seven children were included in this study. Anti-HBs seroprotection level was measured using an enzyme-linked immunosorbent assay (ELISA). The results were analyzed using Chi-square test. Twenty one children $(65.6 \%)$ with ALL and 13 children $(37.1 \%)$ without malignancy showed anti-HBs seroprotection. The difference was statistically significant with p-value of 0.020 (prevalence ratio $[\mathrm{PR}]=0.3 ; 95 \% \mathrm{Cl}=0.11-0.84$ ). Both groups showed no significantly difference of anti-HBs seroprotection according to either female gender, risk classification, or phase of chemotherapy with p-value of 0.38 (PR $=4 ; 95 \% \mathrm{Cl}=1.05-15.2$ ), 0.248 ( $\mathrm{PR}=3.37 ; 95 \%$ $\mathrm{Cl}=0.58-19.6$ ) or 0.214 , respectively. In conclusion, the proportion of anti-HBs seroprotection in children with ALL is higher than those without malignancy.
\end{abstract}

\section{ABSTRAK}

Anak dengan leukemia limfoblastik akut (LLA) yang mendapat kemoterapi mempunyai risiko tinggi terinfeksi hepatitis $B$. Efek proteksi vaksinasi hepatitis B yang pernah didapat sebelumnya pada anak tersebut belum pernah diteliti di Indonesia. Tujuan penelitian ini adalah untuk mengetahui perbedaan proporsi seroproteksi anti-HBs pada anak dengan LLA dengan anak yang tidak mengalami keganasan pasca vaksinasi hepatitis B. Penelitian ini menggunakan rancangan potong lintang dilakukan pada bulan Januari-Februari 2012 di RSUP Dr. Sardjito. Subyek penelitian terdiri dari kelompok penderita LLA yang mendapat kemoterapi dan kelompok yang tidak mengalami keganasan berusia 1-15 tahun yang pernah mendapat vaksinasi hepatitis B. Sebanyak 67 anak diikutsertakan dalam penelitian ini. Semua subyek penelitian diperiksa seroproteksi antiHBsnya menggunakan enzyme-linked immunosorbent assay (ELISA). Analisis hasil data menggunakan uji Chi-square. Proporsi seroproteksi anti-HBs pada LLA sebesar 65,6\% sedangkan kelompok tanpa keganasan sebesar $37,1 \%$. Perbedaan proporsi ini bermakna secara statistik dengan nilai $p=0,020$ (rasio prevalensi $[R P]=0,3 ; 95 \% \mathrm{Cl}=0,11-0,84$ ). Tidak ada perbedaan proporsi seroproteksi anti-HBs antara kedua kelompok berdasarkan jenis kelamin perempuan, klasifikasi faktor risiko maupun fase kemoterapi dengan nilai $\mathrm{p}$ masing-masing adalah $0,38(\mathrm{RP}=4$; $95 \% \mathrm{Cl}=1,05-15,2), 0,248(\mathrm{RP}=3,37 ; 95 \% \mathrm{Cl}=0,58-19,6)$ dan 0,214 . Sebagai simpulan, proporsi

\footnotetext{
* corresponding author: yustin_pediatric@yahoo.com
} 
seroproteksi anti-HBs kelompok anak LLA pasca vaksinasi hepatitis B lebih tinggi dibandingkan dengan kelompok anak tanpa keganasan.

Keywords : anti-HBs seroprotection level - post hepatitis B vaccination - acute lymphoblastic leukemia - Indonesian cases

\section{INTRODUCTION}

Hepatitis B virus (HBV) infection is a worldwide public health problem of major concern. According to the most recent estimate, $6 \%$ or 378 million people worldwide are chronically infected HBV. Hepatitis B virus is estimated to be resposible for 500,000-700,000 deaths annually ${ }^{1}$ Indonesia is moderate-high endemic country of hepatitis B with the prevalence of hepatitis $B$ surface antigen (HBsAg) of 9.4\% (2.5-36.1\%). ${ }^{2}$

Hepatitis B virus can be transmitted both vertically and horizontally, through sexual or household contact, or by unsafe injections. Vaccination against HBV is highly effective at a relatively low cost. Therefore, World Health Organization has been promoting the universal use of this vaccination since 1991. The 3-dose series of hepatitis B vaccine according to Indonesian Immunization Program will lead to an anti-HBs seroprotection response of at least $10 \mathrm{mIU} / \mathrm{mL}$ at almost $100 \%$ of infants, children and adolescents. ${ }^{2}$ Hepatitis B vaccination can induce immunologic memory for at least 15 years. ${ }^{3}$ However, between $5-10 \%$ population have less or no response to hepatitis B vaccination.

Children with malignancies have an increased risk for vaccine-preventable diseases, such as hepatitis B. Hepatitis B infection is a major comorbidity of acute lymphoblastic leukemia (ALL), which may affect the outcome of ALL treatment. Children with ALL have high risk for developing hepatitis B infection due to secondary immunosuppression to chemotherapy and radiotherapy, multiple blood transfusions, intravenous medication administration, and invasive procedures. ${ }^{4}$ Either ALL and chemotherapy can induce loss of humoral immunity to viral vaccination antigens. ${ }^{5}$ This study was conducted to evaluate the anti-HBs seroprotection in children with ALL after hepatitis $B$ vaccination.

\section{MATERIALS AND METHODS}

\section{Subjects}

This case-control study was conducted from January to February 2012 at Dr. Sardjito General Hospital, Yogyakarta, Indonesia. The inclusion criteria were children aged 1-15 years with ALL receiving chemotherapy and without malignancy, had hepatitis B vaccination according to Indonesian Vaccination Program. The exclusion criteria were history of jaundice, chronic renal failure requiring hemodialysis, HIV, chronic liver disease, relapse ALL, obesity, malnourishment, and unclear history of hepatitis $B$ vaccination. Additional exclusion criteria for children without malignancy were receiving systemic steroid of $2 \mathrm{mg} / \mathrm{kg} /$ day for $>7$ days or $1 \mathrm{mg} / \mathrm{kg} /$ day for $>1$ month or receiving other immunosuppressive drugs. Written informed consent was obtained from all parents for this study.

\section{Procedure of study}

The study was using consecutive sampling. The sample size was calculated using twoproportion hypothesis test. Each group consisted of 32 subjects. Interviews were performed to obtain demographic data and previous medical history. Vaccination status of patients was obtained from interview and vaccination record 
form (Kartu Menuju Sehat). This study was reviewed and approved by the Health Research Ethics Committee of the Faculty of Medicine, Universitas Gadjah Mada, Yogyakarta, Indonesia.

Blood samples were taken from the subjects by a trained paramedic. The hepatitis B surface antibody (anti-HBs) level was measured using an enzyme-linked immunosorbent assay (ELISA). The anti-HBs level $\geq$ $10 \mathrm{mIU} / \mathrm{mL}$ was considered to be protective level.

\section{Statistical analysis}

The proportions difference of anti-HBs seroprotection between groups were evaluated using Chi-square analysis. Prevalence ratios and $95 \%$ confidence intervals (CI) were calculated and $\mathrm{p}<0.05$ was considered significant.

\section{RESULTS}

In this study, we have analyzed 67 children of whom 32 ALL group and 35 without malignancy group. The average age were 71.6 months \pm 34 months and 107 months \pm 47 months for ALL group and without malignancy group, respectively. The ALL group consisted of 21 (65.6\%) standard risks and 25 (78.1\%) phases of maintenance. The average duration of chemotherapy was 11.5 months.

TABLE 1. Characteristics of subjects

\begin{tabular}{lccc}
\hline & \multicolumn{2}{c}{ Groups } & \\
\cline { 2 - 3 } Characteristics & $\begin{array}{c}\text { Acute lymphoblastic } \\
\text { leukemia } \\
(\mathrm{n}=32)\end{array}$ & $\begin{array}{c}\text { Without } \\
\text { malignancy } \\
(\mathrm{n}=35)\end{array}$ & $\mathrm{p}$ \\
\hline Agc (month) & $15(46.9 \%)$ & $6(17.1 \%)$ & \\
- $12-60$ & $15(46.9 \%)$ & $14(40 \%)$ & 0.001 \\
- $61-120$ & $2(6.2 \%)$ & $15(42.9 \%)$ & \\
- $121-180$ & $13(40.6 \%)$ & $15(42.9 \%)$ & 0.853 \\
Sex & $19(59.4 \%)$ & $20(57.1 \%)$ & 0.80 \\
- Boy & & & \\
- Girl & & & \\
\hline
\end{tabular}

The age range of this study was 1-15 years, because the hepatitis $B$ vaccination program was introduced in all provinces in Indonesia since 15 years ago. ${ }^{6}$ There was significantly difference of age distribution $(p=0.001)$ between ALL group and without malignancy group (TABLE 1). It might due to wide range of age causes the data become heterogeneous. Most children in ALL group were aged $>10$ years, whereas most children in without malignancy group were aged 5-15 years. There was no significantly difference in sex distribution $(\mathrm{p}=$ 0.853 ) between two groups (TABLE 1).

The proportion of anti-HBs seroprotection in ALL group (65.6\%) was greater than those in without malignancy group $(37.1 \%)$, and the difference was statistically significant with $\mathrm{p}$ value of $0.020(\mathrm{PR}=0.3 ; 95 \% \mathrm{CI}=0.11-0.84)$ (TABLE 2). 
TABLE 2. Anti-HBs seroprotection between ALL group and non-malignancy group

\begin{tabular}{|c|c|c|c|c|}
\hline \multirow{2}{*}{ Variables } & \multicolumn{2}{|c|}{ Protective } & \multirow[b]{2}{*}{$\mathrm{p}$} & \multirow{2}{*}{$\frac{\text { Ratio prevalence }}{(95 \% \mathrm{CI})}$} \\
\hline & Yes & $\mathrm{No}$ & & \\
\hline $\begin{array}{l}\text { Characteristics } \\
\text { - ALL } \\
\text { - Non ALL } \\
\text { Age }\end{array}$ & $\begin{array}{l}21(65.6 \%) \\
13(37.1 \%)\end{array}$ & $\begin{array}{l}11(34.4 \%) \\
22(62.9 \%)\end{array}$ & 0.02 & $0.3(0.11-0.84)$ \\
\hline $\begin{array}{l}\text { 12-60 months } \\
\text { - ALL } \\
\text { - Non ALL } \\
61-120 \text { months }\end{array}$ & $\begin{array}{c}9(60 \%) \\
4(66.7 \%)\end{array}$ & $\begin{array}{c}6(40 \%) \\
2(33.3 \%)\end{array}$ & 0.77 & $0.75(0.1-5.47)$ \\
\hline $\begin{array}{l}\text { - ALL } \\
\text { - Non ALL }\end{array}$ & $\begin{array}{c}10(66.7 \%) \\
5(35.7 \%)\end{array}$ & $\begin{array}{l}5(33.3 \%) \\
9(64.3 \%)\end{array}$ & 0.09 & $3.6(0.78-16.67)$ \\
\hline $\begin{array}{l}\text { 121-180 months } \\
\text { - ALL } \\
\text { - Non ALL }\end{array}$ & $\begin{array}{l}2(100 \%) \\
4(26.7 \%)\end{array}$ & $\begin{array}{c}0(0 \%) \\
11(73.3 \%)\end{array}$ & 0.04 & $3.75(1.62-8.68)$ \\
\hline $\begin{array}{l}\text { Sex } \\
\text { Boy }\end{array}$ & & & & \\
\hline $\begin{array}{l}\text { - ALL } \\
\text { - Non ALL }\end{array}$ & $\begin{array}{c}9(70 \%) \\
7(46.7 \%)\end{array}$ & $\begin{array}{c}4(30 \%) \\
8(53.3 \%)\end{array}$ & 0.23 & $2.57(0.54-12.1)$ \\
\hline $\begin{array}{ll}\text { Girl } & \\
\text { - } & \text { ALL } \\
\text { - } & \text { Non ALL } \\
\end{array}$ & $\begin{array}{c}12(63.1 \%) \\
6(30 \%) \\
\end{array}$ & $\begin{array}{l}7(36.9 \%) \\
14(70 \%) \\
\end{array}$ & 0.38 & $4(1.05-15.2)$ \\
\hline
\end{tabular}

\section{DISCUSSION}

Our study clearly demonstrated that the proportion of anti-HBs seroprotection was significantly greater in ALL group than nonmalignancy group. Our result was different from Alavi et al. ${ }^{7}$ that showed no significant difference of anti-HBs seroprotection between newly diagnosed ALL group and healthy children group or between completedchemotherapy ALL group and healthy children group.

Zignol et al. ${ }^{8}$ demonstrated that $56 \%$ children with ALL still have anti-HBs seroprotection after completion of chemotherapy. Baytan et al. ${ }^{9}$ reported that approximately $56 \%$ children with ALL who had previous Hepatitis B vaccination revealed less anti-HBs seroprotection during chemotherapy. Fioredda et al. ${ }^{10}$ showed that $81 \%$ children with ALL who completed chemotherapy within 10 months still have anti-HBs seroprotection.
Cheng et al. ${ }^{11}$ reported that $53.9 \%$ children with ALL before chemotherapy showed anti-HBs seroprotection and $30 \%$ of them still had antiHBs seroprotection after completing chemotherapy.

Besides vaccination, the anti-HBs seroprotection could be also stimulated by hepatitis B infection. Children with ALL have a high risk for developing hepatitis B infection due to multiple blood transfusions. There was significantly association between the amount of blood transfusion and the increase of hepatitis B infection within 6 months of chemotherapy $(p=0.03)$ and after chemotherapy completion $(p=0.02)$. The prevalence of hepatitis B infection in children with malignancy in Egypt were $3.6 \%, 18.2 \%$, and $34.2 \%$ at first diagnosis, after 6 months of chemotherapy, and after chemotherapy completion, respectively. ${ }^{12}$

Tavil et al. ${ }^{13}$ reported that the prevalence of hepatitis B and hepatitis C infection in Turkey 
was $15 \%$ and $1.9 \%$ of whom most children were high-risk group. The study also showed that there was significant difference in number of blood transfusions between high-risk group and low-risk group $(\mathrm{p}<0.001)$. The anti-HBs prevalence in blood donors in Indonesia was $8.8 \% .{ }^{14}$ The prevalence of hepatitis B infection in ALL children in Indonesia is not available yet. The prevalence of anti-HBs in children with malignancy in Malaysia is $22 \% .^{15}$

This study showed significantly difference of anti-HBs seroprotection level between groups according to age distribution, thus the age was considered as a confounding factor. However after adjustment, a significantly difference between groups only shown by the aged 121180 months sub-group with p-value of 0.04 $(\mathrm{PR}=3.75 ; 95 \% \mathrm{CI}=1.62-8.68)$. The difference might due to small samples (2 subjects) for the aged 121-180 months sub-group. There were no significant differences in anti-HBs seroprotection between groups according to age and gender with p-value of 0.262 and 0.375 $(\mathrm{PR}=1.5 ; 95 \% \mathrm{CI}=0.58-4.13)$, respectively. Zignol et al. ${ }^{8}$ reported the effect of chemotherapy to development of polio, tetanus, hepatitis B, measles, rubella, mumps in ALL children who had previously vaccinated. The study showed that young age $(\mathrm{p}=0.002 ; \mathrm{RR}=7.1$; $95 \% \mathrm{CI}=2.1-23.8)$ and female gender $(\mathrm{p}=0.02$; $\mathrm{RR}=3.6 ; 95 \% \mathrm{CI}=1.2-10.6)$ were predictor factors for immunity response failure to measles vaccine not others.

In the sub-group ALL analysis, there were no significantly differences between groups according to risk classification $(\mathrm{p}=0.248$; $\mathrm{PR}=3.37 ; 95 \% \mathrm{CI}=0.58-19.6)$ and chemotherapy phases $(\mathrm{p}=0.214)$. Van Tilburg et al. ${ }^{16}$ reported that there was a decrease of specific antibodies to diphtheria in the high-risk ALL group compared to the medium-risk one $(p=0.033)$.

The range of anti-HBs level in the without malignancy group was from $<2$ to $545 \mathrm{mIU} / \mathrm{mL}$ and the proportion of anti-HBs seroprotection was $37.1 \%$. The proportion of anti-HBs seroprotection were $66.7 \%, 35.7 \%$, and $26.7 \%$ for the aged 12-60 months, 61-120 months and 121-180 months sub-group, respectively. The results indicated that the proportion of anti-HBs seroprotection in our subjects were low, suggested that the hepatitis B vaccination does not have a long-term protection and declines with time.

Suraiyah et al. ${ }^{17}$ reported that the proportion of anti-HBs seroprotection was $38 \%$ in children aged 10-12 years after primary series of hepatitis B immunization. But et al. ${ }^{18}$ showed that the proportion of anti-HBs seroprotection were $81.8 \%, 73 \%$, and $68.2 \%$ for 10 years, 15 years and 20 years after vaccination, respectively. Other reports showed the proportion of anti-HBs protection in 15-year period after vaccination were $75.8 \%{ }^{19}$ and $68.82 \% .^{20}$ Poovorawan et al. ${ }^{21}$ observed the proportion of anti-HBs seroprotection in 20-year period after vaccination was $60.5 \%$.

Recently, Indonesia is the only country with a national policy of Hepatitis B vaccination using the Uniject ${ }^{\mathrm{TM}}$ method, including outsidethe-cold-chain for delivery of Hepatitis B vaccine birth dose. ${ }^{22}$ Immunogenicity following three doses of vaccine was not significantly difference between infants receiving Hepatitis $\mathrm{B}$ birth dose vaccine using Uniject ${ }^{\mathrm{TM}}$ method and standard method. ${ }^{23}$

The significantly difference of anti-HBs seroprotection according to age distribution might due to lack of initial data of anti-HBs among groups in this study. Anti-HBs seroprotection will decrease with age. The different results between our study and previous reports because of difference in immunization schedule, measurement of the anti-HBs levels, and type and dose of chemotherapy used for ALL.

The limitation of this study was most participants (97\%) did not bring Kartu Menuju 
Sehat (KMS). To reduce the bias, we interviewed in detail about the schedule, frequency, place, person who gave hepatitis B vaccination. Other limitation was wide age-range subjects.

\section{CONCLUSION}

The proportion of anti-HBs seroprotection in children with ALL is higher than those without malignancy. Furthermore, additional studies with age-matched controls, narrow age-range and complete initial data of anti-HBs are necessary to clarify this result.

\section{ACKNOWLEDGEMENTS}

Authors would like to thank Head of Department of Pediatric, Faculty of Medicine, Universitas Gadjah Mada/Dr. Sardjito General Hospital for his permission to conduct this study.

\section{REFERENCES}

1. Zanetti AR, Van Damme P, Shouval D. The global impact of vaccination against hepatitis B: a historical overview. Vaccine 2008; 26(49):626673.

2. Hidayat B, Pujiarto PS. Hepatitis B. Dalam: Ranuh IGN, editor. Pedoman Imunisasi di Indonesia. Jakarta: Badan Penerbit Ikatan Dokter Anak Indonesia. 2008; 135-42.

3. Chen DS. Hepatitis B vaccination: the key towards elimination and eradication of hepatitis B. J Hepatol 2009; 50(4):805-16.

4. Ghosh N, Mannan MA, Monjur F, Rizwan F, Salim AF. Escalated regimen of hepatitis $B$ vaccine in childhood hematological malignancies while on chemotherapy. Southeast Asian J Trop Med Public Health 2010; 41(3):555-61.

5. Nilsson A, De Milito A, Engstrom P, Nordin M, Narita M, Grillner L, et al. Current chemotherapy protocols for childhood acute lymphoblastic leukemia induce loss of humoral immunity to viral vaccination antigens. Pediatrics 2002; 109(6):e91.

6. Muhadir A. Program imunisasi Hepatitis B di Indonesia. Naskah dipresentasikan dalam Seminar World Hepatitis B, Yogyakarta. 2010.
7. Alavi S, Rashidi A, Arzanian MT, Shamsian B, Nourbakhsh K. Humoral immunity against hepatitis B, tetanus, and diphtheria following chemotherapy for hematologic malignancies: a report and review of literature. Pediatr Hematol Oncol 2010; 27(3):188-94.

8. Zignol M, Peracchi M, Tridello G, Pillon M, Fregonese F, D'Elia R, et al. Assessment of humoral immunity to poliomyelitis, tetanus, hepatitis B, measles, rubella, and mumps in children after chemotherapy. Cancer 2004; 101(3):635-4.

9. Baytan B, Gunes AM, Gunay U. Efficacy of primary hepatitis B immunization in children with acute lymphoblastic leukemia. Indian Pediatr 2008; 45(4):265-70.

10. Fioredda F, Plebani A, Hanau G, Haupt R, Giacchino M, Barisone E, et al. Re-immunisation schedule in leukaemic children after intensive chemotherapy: a possible strategy. Eur J Haematol 2005; 74(1):20-3.

11. Cheng FW, Leung TF, Chan PK, Leung WK, Lee $\mathrm{V}$, Shing MK, et al. Recovery of humoral and cellular immunities to vaccine-preventable infectious diseases in pediatric oncology patients. Pediatr Hematol Oncol 2010; 27(3):195-204.

12. Mostafa A, Ebeid E, Monsour T, Amin MD, Sidhom I, Khairy A, et al. Seroprevalence of hepatitis $\mathrm{B}$ and $\mathrm{C}$ in pediatric malignancies. Journal of the Egyptian Nat Cancer Inst 2003; 15(1):pp 32-42.

13. Tavil B, Cetin M, Tuncer M, Gumruk F, Yuce A, Demir H, et al. The rate of hepatitis B and $\mathrm{C}$ virus infections and the importance of HBV vaccination in children with acute lymphoblastic leukemia. Hepatol Res 2007; 37:498-502.

14. Sulaiman HA, Julitasari, Sie A, Rustam M, Melani $\mathrm{W}$, Corwin A, et al. Prevalence of hepatitis B and $\mathrm{C}$ viruses in healthy Indonesian blood donors. Trans R Soc Trop Med Hyg 1995; 89(2):167-70.

15. Menon BS, Aiyar S. The prevalence of hepatitis B surface antigen and anti-HCV antibody in paediatric oncology patients in Hospital Universiti Sains Malaysia. Med J Malaysia 1997; 52(4):3314.

16. van Tilburg CM, Bierings MB, Berbers GA, Wolfs TF, Pieters R, Bloem AC, et al. Impact of treatment reduction for childhood acute lymphoblastic leukemia on serum immunoglobulins and antibodies against vaccine-preventable diseases. Pediatr Blood Cancer 2012; 58(5):701-7. 
17. Suraiyah, Oswari H, Poesponegoro HD. Proporsi seroproteksi hepatitis B pada usia 10-12 tahun dengan riwayat imunisasi dasar hepatitis B lengkap pada dua Sekolah Dasar di Jakarta. Sari Pediatri 2008; 9(6):423-8.

18. But DY, Lai CL, Lim WL, Fung J, Wong DK, Yuen MF. Twenty-two years follow-up of a prospective randomized trial of hepatitis $B$ vaccines without booster dose in children: final report. Vaccine 2008; 26(51):6587-91.

19. Ni YH, Chang MH, Huang LM, Chen HL, Hsu HY, Chiu TY, et al. Hepatitis B virus infection in children and adolescents in a hyperendemic area: 15 years after mass hepatitis B vaccination. Ann Intern Med 2001; 135(9):796-800.

20. Zhang L, Xu A, Yan B, Song L, Li M, Xiao Z, et al. A significant reduction in hepatitis $B$ virus infection among the children of Shandong
Province, China: the effect of 15 years of universal infant hepatitis B vaccination. Int J Infect Dis 2010; 14(6):483-8.

21. Poovorawan $Y$, Chongsrisawat V, Theamboonlers A, Bock HL, Leyssen M, Jacquet JM. Persistence of antibodies and immune memory to hepatitis B vaccine 20 years after infant vaccination in Thailand. Vaccine 2010; 28(3):730-6.

22. Creati M, Saleh A, Ruff TA, Stewart T, Otto B, Sutanto A, et al. Implementing the birth dose of hepatitis B vaccine in rural Indonesia. Vaccine 2007; 25(32):5985-93.

23. Otto BF, Suarnawa IM, Stewart T, Nelson C, Ruff TA, Widjaya A, et al. At-birth immunisation against hepatitis B using a novel pre-filled immunisation device stored outside the cold chain. Vaccine 1999; 18(5-6):498-502. 